\title{
John McMasters' Contributions to Aircraft Design Education
}

\author{
Russell M. Cummings ${ }^{1}$ \\ United States Air Force Academy, USAF Academy, CO, 80840
}

\begin{abstract}
John McMasters was intensely interested in two seemingly diverse pursuits: aircraft design and technical work force development. The later pursuit often got John involved in encouraging the development and improvement of engineering education, especially aircraft design education. He spent countless hours considering the issues that contribute to good design education, and was a strong proponent of programs that would encourage students to become interested in design. An overview of John's ideas on aircraft design education will be presented based on discussions with John, as well as papers that we co-authored. In addition, John had a long talk with me just prior to his death where he outlined his ideas on how the future of aircraft design could be influenced to eventually create "greener" and/or more innovative airplanes. It will be interesting to the aerospace community to see John's notions for this lofty goal.
\end{abstract}

\section{Introduction}

$\mathrm{O}$ $\mathrm{NE}$ of the great pleasures of my professional career was to spend time with John McMasters of The Boeing Company. John was intimately involved with various educational initiatives within Boeing, including the Boeing A.D. Welliver Faculty Summer Fellowship program, in which I participated during the summer of 2000. As fate would have it, I was assigned to John as my Boeing contact, and we had a wonderful summer thinking, talking, exploring, and writing. The outcome of that summer was a fairly long list of publications for technical meetings, magazines, and engineering journals. ${ }^{1-11}$ These efforts led to John becoming a great friend of mine, and I look forward to sharing my experiences with John related to aircraft design education.

Perhaps a little background about John and his career are in order to better understand how he "ticked" (see Fig. 1 , which was created and titled by John). John had a love for airplanes from the age of four (John fell in love with airplanes in 1943 when he his uncle gave him a private "air show" in a P-38). ${ }^{12}$ According to John, "Knowing from the beginning what I wanted to do when I grew up made life and school very much easier however."

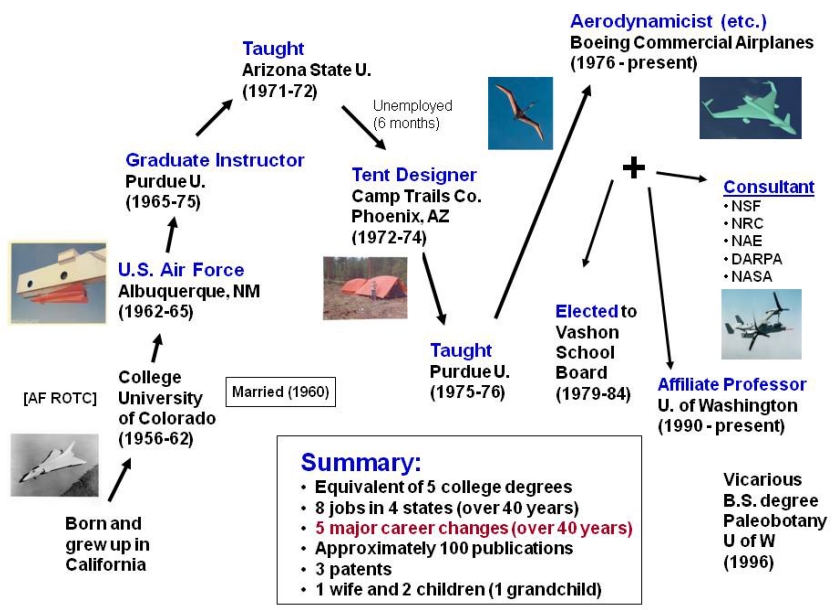

Figure 1. John McMaster's "Brilliant" Career.

John was an Air Force ROTC student at The University of Colorado in the 1950s, where he was strongly

\footnotetext{
${ }^{1}$ Professor of Aeronautics, Department of Aeronautics, AIAA Associate Fellow.
}

American Institute of Aeronautics and Astronautics 092407 
influenced by the design philosophy of K.D. Wood. Upon graduation John was commissioned into the U.S. Air Force, where he served for three years as a missile systems project officer at the Air Force Special Weapons Center in New Mexico. "The Air Force was a good experience for me in many ways. I was allowed to serve (as a mere $1^{\text {st }}$ Lt. at the ripe age of 24) as the "chief engineer/designer" on our missile project and was later awarded the Air Force Commendation medal for the effort. I also learned a great deal working with truly exceptional and dedicated people." 12 John always held a soft spot for the Air Force and appreciated the opportunities he received while serving.

While John knew that he wanted to be a designer, he assumed that he would be able to make a better living as a teacher, so he now spent years collecting the education and experience that would be necessary for that ultimate goal. He completed his Ph.D. at Purdue University, with teaching stints mixed in at both The University of Arizona and Purdue. "My initial experience teaching aerodynamics and airplane design as a graduate instructor did convince me that I had made a good choice in seeking a teaching career." ${ }^{12} \mathrm{He}$ also designed tents for awhile during this "low" period in his career that happened to coincide with the early 1970s "bust" of the aerospace industry. In spite of this, John believed that, "These seeming adverse turns of fortune have since led me to the conclusion that there is no job, no matter how apparently "menial" that can not provide valuable learning and experience. In the end, I have profited professionally (if not economically) from the sum of all my various career changes, even though exactly how this would all work out was far from obvious at the time."12

Finally, in 1976, John joined Boeing as an aerodynamicist, and things really started to look up (both for him and for us). The unusual career and education path he had followed were now going to serve him well as he began his aircraft design career. John made significant technical contributions in the field of high-lift aerodynamics, sailplanes, vortex generators, very large aircraft design, undersea gliders, smart wings, and many other concepts. During this amazing career, John learned many lessons, most importantly: ${ }^{12}$

- The importance of having a vivid "vision" of the future

- The value of mentors, role models, and networking

- Developing and holding a "systems perspective"

- Design is not only the essence of engineering, it is a "life skill"

This paper will try to place these lessons in the context of John's passion for engineering education (in general) and aircraft design education (in particular).

\section{Twin Professional Passions}

While it could be possible to view John McMaster's engineering interests as being eclectic and unrelated, John certainly did not view them that way. John saw his interests as being completely integrated and eminently practical. And while it might also be possible to see John just as a "brainstormer" who only came up with ideas but did not know how to make them work, we will see that his ideas and concepts were strongly grounded in a solid technical foundation. It is just that he understood the technical concepts so well that he really did not spend any time thinking about issues like aspect ratio or power required - these were the appetizers for his deeply fertile and imaginative application meals.

The way John liked to describe his interests were as "twin professional passions" with a long list of associated "hobbies". Figure 2 shows John's own pictorial description of these interests. These passions were airplanes (which included aerodynamics and aircraft design) and education (which included aircraft design education and technical workforce development). While that is easy to see from our perspective now, it was not as obvious to John as he was going through his life:

"My interest in education and teaching developed much more slowly and did not really become clear to me until much later. In retrospect, I can now see that the seeds for that had been firmly planted from birth. Both my parent's family stock had moved west in the early 1900's to work as laborers in the developing oil field in California. None had more than a high school education, but most were well educated by today's standards and education was a strong value among them. Thus, despite the hardships of the Depression, both my parents were encouraged to go on to college with both eventually obtaining masters degrees, my father's in petroleum geology and my mother's in history in which she also obtained a teaching certificate." 12 
For many of us, these might be two very interesting, but very unrelated pursuits. For John, these two passions were intricately linked. His associated "hobbies" included paleontology, archaeology, cultural anthropology, and cognitive psychology. How could these "hobbies" be considered "associated"? To John, there was no mystery-this was a well coordinated and necessary list of concepts and ideas that co-existed in order to achieve his goal: to continue developing innovative and applicable aircraft. John saw the technical workforce development as another engineering problem that needed to be solved, and put his full creativity into solving it. This is one reason John finished his career at the Ed Wells Initiative, a joint Boeing/SPEAA program to improve the engineering work force at The Boeing Company.

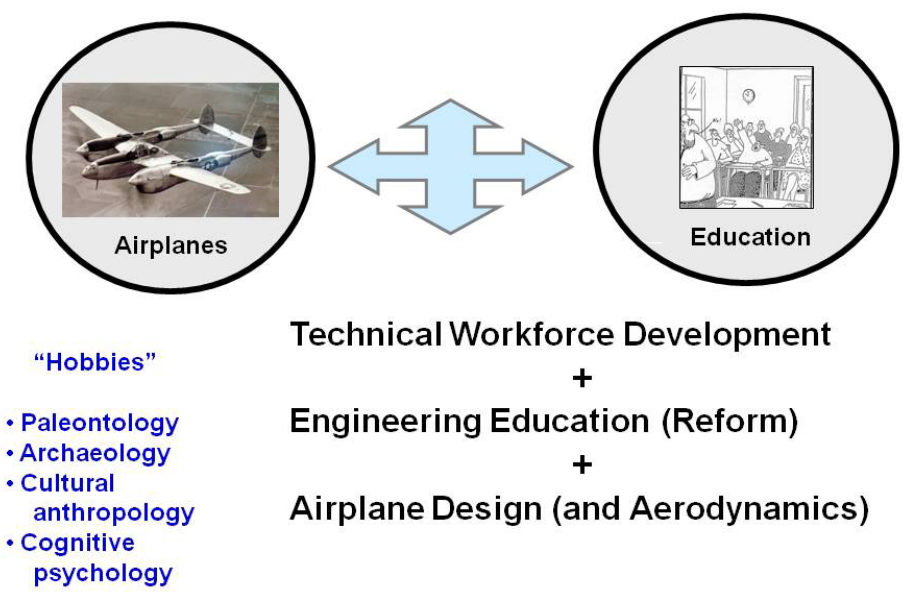

Figure 2. John McMaster's Twin Professional Passions and Hobbies.

John was always thinking, and he no doubt saw that his varied interests and abilities could find a unifying point of concentration. Whether he knew all of this in advance, or simply was creative in consolidating his passions, he definitely had a vision that incorporated all of the passions and hobbies shown in Fig. 2. While he published over 100 papers in his career, many of them were about education and the role of industry in improving aircraft design education (see for example, Refs. 13-16).

\section{Aircraft Design Background}

It is easy to assume that a truly creative person like John McMasters was not necessarily an expert of the engineering science that governed aircraft design: nothing could be further from the truth. In fact, John was fond of saying that too many people were naïve of the laws of nature and spent considerable time and energy being "creative" about impossible concepts. As was previously stated, John made significant contributions in a variety of aerodynamic and aircraft design areas, including high-lift aerodynamics ${ }^{17}$ sailplanes,${ }^{18}$ vortex generators, very large aircraft design, ${ }^{19}$ undersea gliders, smart wings, and many other concepts. Walt Gillette, a senior executive at Boeing, and John once wrote their own version of the The Book of Genesis, at least one from the perspective of The Aerospace System Designers perspective, as shown in Fig. 3. Specifically, this clever and humorous account shows that they were not only well versed in science and engineering, but also realized that there were non-technical constraints on design, including the price for a new system. 


$$
\begin{aligned}
& \frac{\text { The 䀦ook of ofencsis }}{\sim \text { from } ~} \\
& \text { The Aerospace Systern Designers Bible } \\
& \text { By W. Gilldte \& J.H.McMasters } \\
& \mathscr{A}_{\text {nd }} \text { on the first day there was gravity and the spirit of Newton said: } \\
& F=K \frac{m 1 m 2}{r^{2}} \\
& \text { and Matters become weighty. } \\
& \text { And then there was boundless energy and it was consolidated and } \\
& \text { Einstein quoth: } \\
& E=m c^{2} \\
& \text { and there was Motion, but it was merely transverse. } \\
& \text { Anid on the third day, from the heavens, a voice cried out: } \\
& \text { and there was Lift. } \\
& C_{L}=\iint_{x y}\left(C_{P_{L}}-C_{P_{U}}\right) d x d y \\
& \text { 积ut on the fourth day, the Devil said: } \\
& C_{D}=C_{D P_{\text {trin }}}+C_{L}^{2} / \pi \mathbb{R} \text { e }+\Delta C_{D p}+\Delta C_{D M}+\Delta C_{D_{P} \text { bugs }} \\
& +\left(\Delta C_{D_{\text {Bourancry }}}\right)+C_{L} \sin \propto \text { upflow } \\
& \left.+Q_{3} \int(\text { erf })^{\text {nerf }} d z-2 / 3 \text { (Management Requircmert }\right) \\
& +\Delta C_{D_{\text {TRIM }}}-C_{D_{\text {BLOCKAGE }}}-C_{D_{\text {TRIP }}}+C_{D_{\text {BASE }}}+2 \sigma+\text { H.O.T. }+C \\
& \text { and there was Drog. } \\
& \text { Din the fifth day a tiny vorce from the wilderness cried out: } \\
& \text { "... dorit foxget stability and control." } \\
& \text { And this was echoed by various multitudes crying: } \\
& \text { "...envikonmental control systans, ground support equiptrment, } \\
& \text { far into the right of the sixth day. } \\
& \text { and } \mathrm{Ctc}_{\mathrm{c}} \\
& \text { And an the iast day, the spurit of Maynard Kaynes proclainked: } \\
& \text { "He who controls the purse strings controls the podicy." } \\
& \text { and thare was Econamic Realit } \\
& \text { Caveat Emptor. Alaxn. }
\end{aligned}
$$

\section{Figure 3. The Aerospace System Designers Bible by Walt Gillette and John McMasters.}

In fact, John had a very solid technical and scientific background, which not only informed his design concepts, but aided him in having a big picture view of the aerospace industry. Specifically, John created his own rules of design, which he called the Basic Laws of Aircraft Design:

- Innovation for mere innovation's sake can be a great waste of time (and money) —never invent anything if you don't have to!

- You never get something for nothing-someone, somewhere always pays for lunch

- While the laws of economics are somewhat malleable, the laws of physics are not; thus

- "If it looks good, it will fly good" is a myth that is sometime true

- Simplicity is the essence of true elegance-it can also save weight and/or cost

- If you can't build it, you can't sell or use it

- They who control the purse strings control the policy—-to avoid exercises in futility, learn how to close a business case

John often stated that, "grand concepts are easy-the devil is always in the details." Well, maybe they were easy for John, but as often the case, he was already seeing beyond the concept to the reality of practical issues related to turning the idea into a usable product.

To put some meat on the bones of these rules, John enjoyed showing students and practicing engineers that there indeed were very real limitations on their designs. Specifically:

- In aeronautics, we live in a closed thermodynamic system in a largely Newtonian universe, thus:

○ Weight $(W)<\operatorname{Lift}(L) ; L=1 / 2 \rho V^{2} C_{L} S$

American Institute of Aeronautics and Astronautics 


$$
\begin{aligned}
& \text { ○ } \operatorname{Thrust}(T)>\operatorname{Drag}(D) ; D=1 / 2 \rho V^{2} C_{D} S \\
& \text { ○ } \quad D=D_{\text {parasite }}+D_{\text {induced }}+D_{\text {compressibility }}+\text { H.O.T. (2/3 management requirements) } \\
& \text { - } D_{\text {parasite }} \approx f\left(S_{\text {wet }}, C_{L}, \operatorname{Re}\right) V^{2} \\
& \text { - } D_{\text {induced }} \approx k(L / b)^{2} / V^{2} \approx k(n W / b)^{2} / V^{2}
\end{aligned}
$$

- The sum of the moments equals the time-rate-of-change of angular moment (in a vector sense) [flying is easy-here lies the real challenge]

- Range $_{j e t}=(M L / D)(T S F C)^{-1} \log _{e}\left(W_{\text {initial }} / W_{\text {final }}\right)$

It is safe to say that John truly could "feel" these physical laws and understand how they constrained design. While most of us get lost in the technical details of equations and trade studies, John was always standing there with his head up, looking beyond the calculations toward the creativity and usefulness of the design. In fact, John's career transcended a number of periods of the aerospace industry, something which he did not lament, but rather embraced.

Another thing that John was intimately aware of was how the aerospace industry had changed over the decades. Certainly the original mantra of aircraft design from 1903 to 1990 had been Faster, farther, higher. Once the Cold War was over during the 1990 to 2000 period, the mantra changed to Quicker (to market), better, cheaper (and safer). Many people believed this represented a maturing of the industry and the possible demise of creativity in aircraft design (see Ref. 2). John firmly believed that our lack of vision was the only limitation to creativity, and that several emerging new mantras could be issued for the future, including Safer, better, faster, higher, farther, cheaper, quicker, quieter, cleaner, etc. or Leaner, meaner, greener. Seeing the new, evolved challenges for aircraft design would be key to maintaining a vigorous and innovative group of designers in the aircraft industry.

\section{Attributes of a Good Designer}

John was not merely content to be a good engineer, or a good designer, or a good anything. As was shown in the previous section, John was an integrative thinker, and he always seemed to have a plan for his various interests (or at least he was always looking for a plan!). Instead of just spending the rest of his career designing airplanes (something he was very good at), he started thinking beyond his own place in the company to see how he might impact the bigger picture. Why was he (or others) a good designer? What made someone good at design? Was there a common background or ability of these designers? John wanted to know, and he spent considerable time thinking about what contributed to the attributes of a good designer. Figure 4 shows some of his resulting thinking about what it takes to design. His thoughts were based on those of C.R. Chaplin, but as always, John could not resist in putting his own mark on the issue. Among the attributes that John identified were several abilities that John considered to be ambidextrous (or even schizophrenic), and certainly could not be exhibited at the same time without "short circuiting the brain." For example, he believed that good designers had to naturally be creative, but also critical of their work (a conflict that has led to "writer's block among many great novelists). In fact, John believed that, "One can (and must) learn to switch reflexively from one mode to another as need may arise. This can be done and one can learn how to do it."

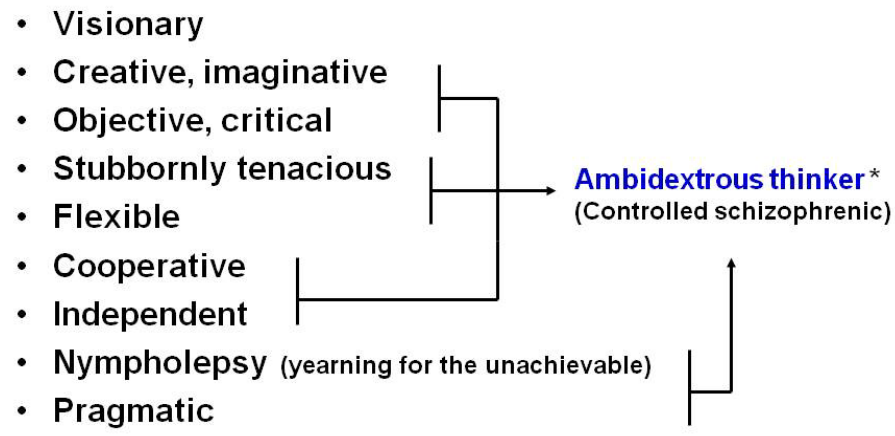

Figure 4. Attributes of a Good Designer (adapted from a list by C.R. Chaplin, U.K. Fellowship of Engineering). 
Some of the possible indicators of a "systems thinker" that John identified included:

- Generic Traits:

$\circ$ Curiosity and eagerness to learn new things

$\circ$ Breadth and well as Depth of Knowledge and Experience

○ Interest in Concepts, Meaning and Context ("big picture" thinking)

- Flexibility and Adaptability to Change:

○ "What are your hobbies and interests outside of work and/or specific job assignments?"

○ "What is your work and job assignment history?"

○ "Are you comfortable 'multi-tasking' or do you prefer to focus on one specific job or task at a time?"

$\circ$ "What are your professional growth aspirations? What would you like to be doing 5-10 years from now, professionally or otherwise?"

More than just thinking about what made a good designer, John also thought about how these people could be cultivated and "grown". Among his thoughts on how systems integrator and architects could be encouraged are:

- An identification process of those individuals who have a reasonable probability of being "good at it" (e.g. based on Myers-Briggs or other personality evaluations).

- A strategically-oriented job rotation program (well beyond a particular discipline or a single specific technical area)

- Targeted continuing education and training as needed to provide in-depth foundational rigor and exposure to fundamentals not provided in work assignments

- Targeted work assignments that provide a practicum for dealing with "system problems" of increasing complexity

- Mentoring (lots of mentoring!)

- Special assignments as opportunities arise that provide a non-traditional breadth of knowledge or perspective - or which simply stimulate "systems thinking" (X-plane design-build-test projects, etc.)

- Exposure to important new technologies such as multi-disciplinary optimization (which can be more powerful as learning devices than as mere working tools) - operating like "video games".

- First hand design-build-test project experience

Many companies offer some of these programs, but rarely to the extent that John believed was necessary to truly "grow" configurators. While companies require a wide variety of skills among their engineering employees, John believed that the system integrator was an essential aspect to the development of large scale systems, and that unless the company spent time cultivating these employees the development of new concepts and programs would be greatly hindered.

\section{Reforming Engineering Education}

"Engineering education in the U.S. is more broken than is generally acknowledged." That statement was made by John, and he was not being pessimistic, but realized that we have a lot of work to do in order to attain high quality engineering education. John believed that our future supply of engineering talent is being threatened since current programs are failing to attract and retain an adequate number of students, especially women and minorities. In spite of the fact that John had a Ph.D., he believed that most undergraduate programs still look more like "preparation for Ph.D. programs" than "preparation for professional practice programs". He saw that the great majority of faculty have almost no significant industry experience, and have too little understanding of rapidly evolving employers need. While John would be the first to say that it is not completely the job of the university to educated and train engineers for industrial practice, he believed that it was certainly one of their more important jobs.

John firmly believed that engineering education programs are expensive to offer and costs are rising alarmingly, but at the same time student are not getting full value for their money and are being turned off by the courses being offered (especially women and minorities). Because of this, employers pay the full (often hidden) bill for teaching graduates what they need to know, but are not being taught in school. Instead of just blaming the universities for not fulfilling their mission, John was proactive and encouraged Boeing to work with universities rather than just complain about them. This led John to become a member of the Boeing Higher Education Integration Board (and its 
predecessor the University Relations Process Council). John was also the co-creator of the Boeing-A.D. Welliver Faculty Summer Fellowship program, the Boeing Fellow on Campus program, and the Boeing Outstanding Educator Award program. Finally, he was a co-founder of the Industry-University-Government Roundtable for Enhancing Engineering Education (IUGREE), which existed from 1995 to 2002. John firmly believed that there was a potential major net savings for industry in investing early in the educational process, rather than paying the bill later on.

In spite of these efforts, John believed that major opportunities for reform remained to be exploited. While significant advances had been made in the knowledge of how people learn and develop, much of that knowledge is unknown within engineering academe. Certainly, new teaching methods and curricula organization have been demonstrated at various universities, but many of these ideas had not been widely accepted. John believed that little has changed in the educational delivery system for the past 50 years. However, he firmly believed that the new ABET EC 2000 accreditation rules encourage rather than block educational experimentation (this is something that certainly is debatable, but at least the discussion is going on!). Because of these observations, John posed a puzzle for engineering programs across the country. He believed that educators could find a better way to align the various competing interests within academia to help improve engineering education while still achieving some of the historically important goals of universities.

\section{A. A Puzzle for Engineering Academe}

There are at least three diverse constituencies that need to be satisfied by each department or program within a given (research) university. These constituencies include the university itself (including faculty, administrators, and possibly legislators), students and their parents (and indirectly the public), and employers. Each of these groups has various interests and desires for the university to fulfill, and at time these interests seem to be mutually exclusive (or at least competing). The university certainly wants a good public and peer institution image and reputation. This includes the desire for prestige (personal and vicarious), a steady (generous and pristine) stream of research funding, and high quality students (primarily graduate students for research). Students (and their parents) want a quality education commensurate with the tuition paid and costs incurred while at the university. They also want adequate preparation for a job (or possibly even a career) which is both interesting and satisfying. Of course, students want this to occur as soon as possible! Engineering employers (and other outside parties who depend on program outputs) want graduates (often at the B.S. degree level) who are well prepared for the work for which they are to be hired (at the market rate). Companies would also like for the university to supply continuing educational services which are conveniently available, as well as research results and technical consultation service if the price is right, but these tend to be of a lower priority overall. How can all of these competing interests be satisfied, especially when the primary group in control of the curriculum, the faculty, see their role very differently than the other interest groups?

John was never one to merely complain about a problem. His insights and interests usually led to potential solutions, and this issue was no exception. As outlined in Fig. 5, John believed that there are ways to align the various competing interests described above, but first the problem needed to be defined and understood. Notice that it is certainly possible for these competing interest groups to pull apart academia, making it essentially useless to everyone. That is not what anyone wants, but how can you bring everyone together to achieve all of the goals? That was a problem that John wanted to solve. 


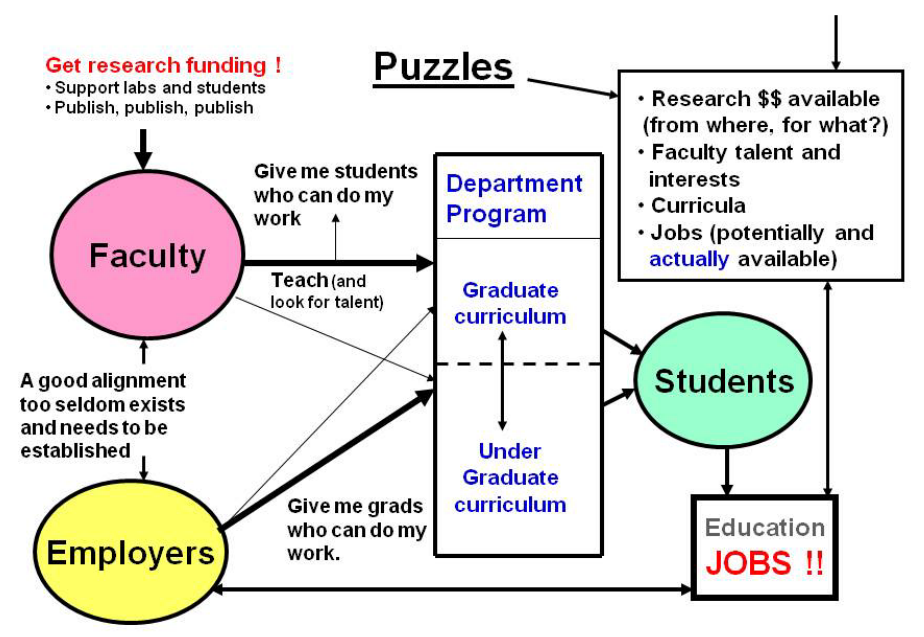

Figure 5. A Puzzle for Engineering Acadame.

John believed that the solution was to create a curriculum with a proper balance between fundamentals (math, engineering sciences, IT, etc.) and provision of in-depth experience in skills and issues important to professional practice. He believed this approach could be fully compliant with the spirit and intent of ABET EC 2000, could provide engineers with the attributes that industry wanted, and also provide a solid foundation for subsequent graduate study, professional practice and continued career-long learning. This would be accomplished by building on the strengths of the graduate education and research programs, but also required a strong emphasis on designbuild-test project experience from the freshman year through graduation. This could be accomplished with a diverse, well qualified faculty with a strong teaching ability, as well as a good research ability. But the faculty would need to be literate in industry and professional practice, and willing and able to function as a team. They should also be exemplars of life-long learning.

This approach also has a great deal of requirements on the external interest groups. Adequate facilities and institutional support are required, including: classroom space suitable for cooperative/collaborative learning pedagogical models, dedicated student design-build-test project labs, laboratory and computational facilities with modern equipment and technician support, strong linkages to Colleges of Business and programs important to professional practice. Also, strong external (industry, government, etc.) relations and support are required, including: the use of adjunct faculty from industry to bring practical aspects to the curriculum, a strong and effective external advisory board with industry, government, peer institution representation (at both departmental and college levels), and effective networks and exchange opportunities with industry, peer university programs (both domestic and international), and alumni. Some descriptions of how this could work may be found in Ref. 11.

The main problem with this approach, according to John, was the reward systems that drive both the university and industry. The faculty reward system (which John believed included more than just tenure) is driven by research and associated prestige, with little or no incentives to devote effort to undergraduate teaching. The industry reward system is driven by near-term needs for business (and career) success, with little or no career incentives to devote effort to university relations. In general, John believed that there was a general lack of communication and shared common vision between the various interest groups. This is exhibited by what John described as a lot of "runners out for a pass," with a limited coordinated vision of the future. He also believed that there was a general ignorance of industry needs from a university perspective (probably because so few professors today have industry experience), as well as little understanding of faculty needs and constraints by industry. Also, John believed that industry and university time scales for change or action are very different, which causes major gaps between expectations and realization.

One of the ways John envisioned the problems inherent with engineering education can be seen in Fig. 6. In 1900 most professional degree programs required four (or fewer) years for pre-professional and professional study. By 1940, the medical professional had drastically changed their educational requirements to include approximately seven years of study, with dental, law, architecture, and business requiring four to five years. During the period from 1900 to 1940, engineering study did not change. From 1980 to the present the differences between engineering and the other professions grew even more dramatic, with most professions requiring between six and eight years (minimum), while engineering remained at four years. 


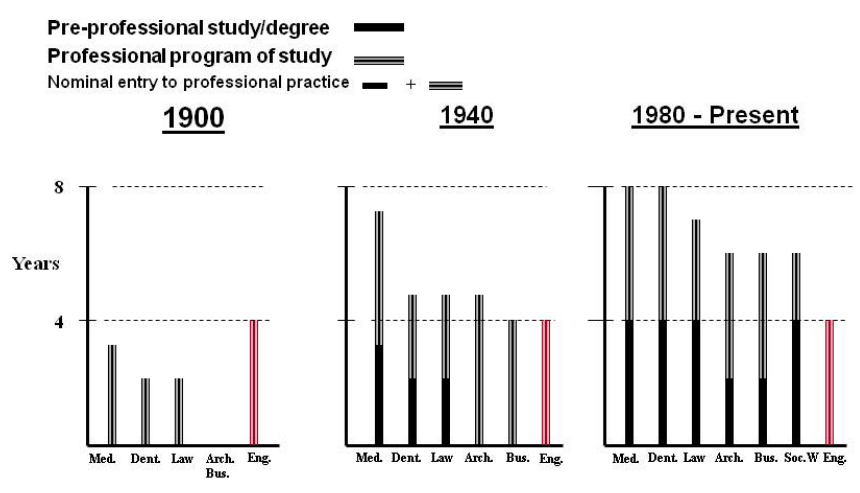

Figure 6. Evolution of Professional Degree Programs.

Part of the problem within engineering education is that no one wants to change their pre-professional study requirements to a five year (or longer) program, since that would place their university at odds with all other universities. Another potential solution is to make a master's degree the required entry-level degree for professional practice, essentially making five years of study the minimum requirement. While this debate has been going on for decades (and certainly will not be resolved here), John believed that this was something that definitely needed to be addressed at a national level, with input from all of the constituency groups involved in the discussion.

\section{B. Aerospace Engineering Curricula as a Large Scale System Integration Training Ground}

Once again, where others see only problems, John saw great opportunity. John strongly believed that the traditional $\mathrm{BS} / \mathrm{MS} / \mathrm{PhD}$ degree structure was a legacy of the 19th century origins of engineering education programs as "vocationally oriented" outgrowths of the science components of liberal arts curricula. He believed this approach was no longer consistent with the needs of a true professional program. First, he believed that aerospace programs were uniquely positioned to lead other engineering programs in evolving toward viewing their curricula as "large scale system integration" training grounds, as shown in Fig. 7. Rather than the traditional vertical discipline view of aerospace engineering (aerodynamics, structures, etc.), John saw all of the disciplines as needing to be integrated into a problem solving curriculum, complete with manufacturing, information technology, and project management elements. This would be accomplished by a design, analysis, test and integration approach, which would eventually require for all of the disciplines to be involved and understood, but not in the traditional approach.

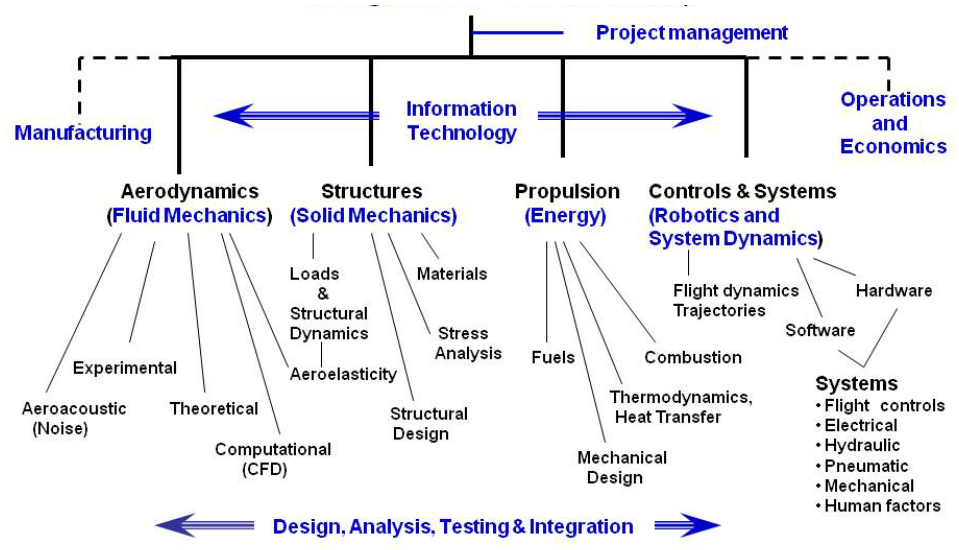

Figure 7. Aerospace Engineering as a Large-Scale, Multidisciplinary Systems Integration Curriculum.

American Institute of Aeronautics and Astronautics 


\section{A Strategy for Engineering Education and Continuing Education}

An overall approach to solving these various problems is shown in Fig. 8. John believed that a re-design of engineering curricula was possible, but that it would require universities offer a number of options for students, depending on which career path they were most interested in. The approach required students to obtain a master's degree as an entry-level degree, but with the option of obtaining a traditional M.S. degree (as preparation for traditional Ph.D. programs) or a professional M. Engr. Degree (for those primarily interested in professional practice. Both approaches would require a B.S degree as a pre-professional degree, with an additional option of proceeding to other professional degree programs (such as medicine, law, or business) once the B.S. degree was obtained. While some universities have attempted to do something similar over the past few decades, I do not believe that these approaches truly meet the goals of John's vision shown below.

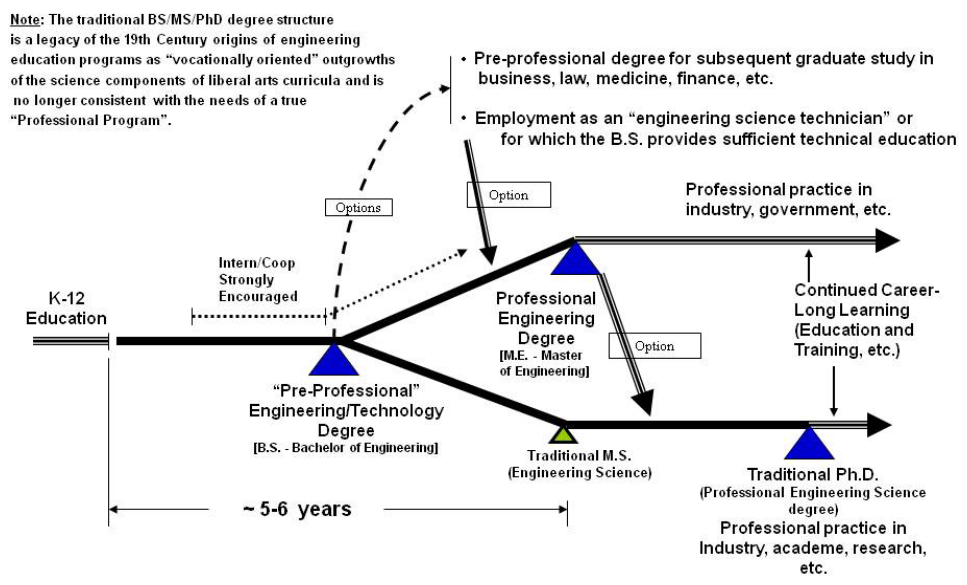

Figure 8. A Possible Degree and Continuing Education Structure for Engineering Education.

\section{Reinvigorating Aircraft Design Education}

It would be a mistake to assume that John was terribly interested in the nuts of bolts of teaching aircraft design. His contribution to aircraft design education was much broader and farther reaching than how to present basic design concepts to students. Based on the presentation of John's passions and hobbies in earlier sections of this paper, it is hopefully clear that what John really wanted to accomplish was to insure a continued pipeline of talented and capable engineers who would be interested in the aerospace industry in general, and in aircraft design in particular. But how can you do this while working at Boeing? By actively participating in the Ed Wells Initiative, IUGREEE, and ABET.

First of all, John firmly believed that airplanes, and the related hobbies that he enjoyed, could serve as a "hook" to get kids interested in science and engineering, as shown in Fig. 9. While he was definitely an airplane lover, like so many others of his generation, John suggested a number of technical hooks to draw kids into fields like physics, chemistry, biology, ecology, and engineering. Among these hooks were airplanes (of course), rockets, astronomy, cars, dinosaurs (one of his hobbies), birds (another of his hobbies), bugs (still another of his hobbies), plants and gardening, computers, etc. While in elementary and middle schools, John foresaw drawing students into math, science, and engineering by giving them practical and fun projects to work on that would use their math skills and innate creativities. Once the students were interested, then courses in science and engineering during high school and college would fill in the knowledge gaps that the students have. In other words, use the interest of the kids to encourage their studies, not the other way around. 


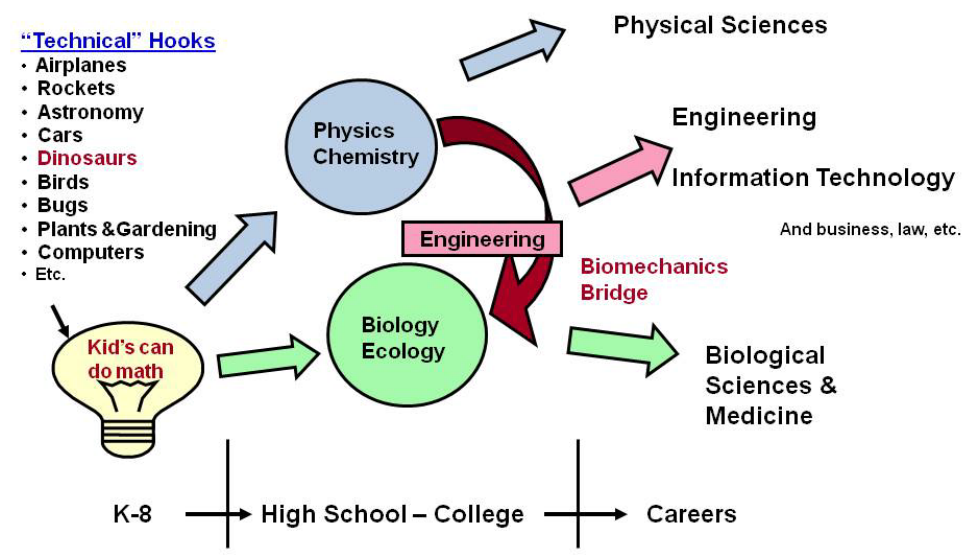

Figure 9. Hooking Kids on Science and Engineering.

This paradigm could also serve within engineering curricula by using projects to create excitement for learning. While this approach has become more fashionable in recent years, John spent many years preaching this concept to whoever would listen. But how would this work in a college curriculum? Based on the concepts presented in the preceding section, John saw that aerospace engineering programs were in a special position to accomplish these goals simply by taking advantage of the inherent systems approach that aviation vehicles require. If students were putting together aerospace systems, they would also be learning about the math and science necessary to overcome the technical challenges common in the industry. This "upside down" approach flew in the face of traditional engineering education approaches of the time, since most people believe that you cannot perform design without the math, science, and engineering science skills already attained (which is why aircraft design is typically viewed as a "capstone" course). An example of a program that John highly encouraged was the sophomore aircraft design curriculum which was initiated at Cal Poly and is described in Ref. 22.

Well, leave it to John to finally show us why he had so many hobbies. Why not use topics such as flying dinosaurs, ${ }^{20}$ flying insects, ${ }^{21}$ and birds to produce interest and excitement about aviation (see Fig. 10)? An important by-product of this interest could also be that students would learn about new approaches and come up with innovative ideas because of their interest in biological systems.
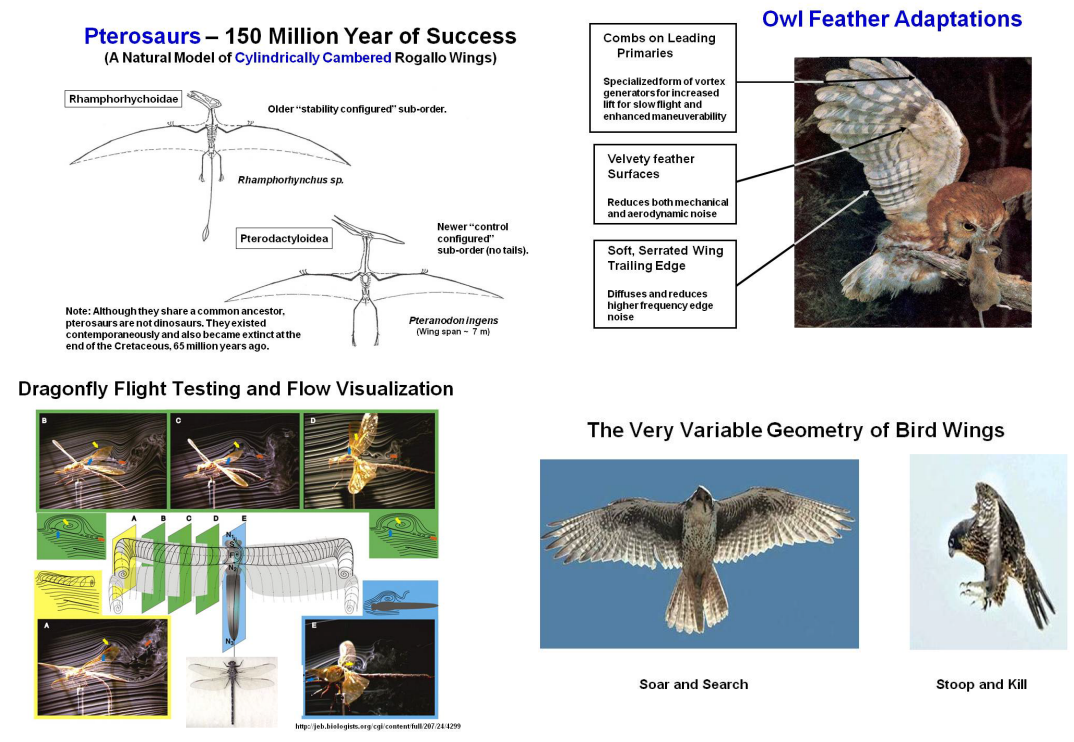

Figure 10. Four Possible Hooks for Aerospace Interest: Pterosaurs, Owls, Insects, and Hawks. 
So, you may be asking yourself, "what can be done with this stuff?" John was way ahead of you! John saw the origins of new concepts and exciting new aircraft design approaches in these fields of study. The ability to design smart wings, or more efficient vehicles, or new applications of existing technology, all existed in these studies, as shown in Fig. 11. And John was optimistic that groups of interested and motivated students would find future concepts that would help to make the aerospace industry a vibrant and exciting field for students today, just as it had been for students of John's generation.

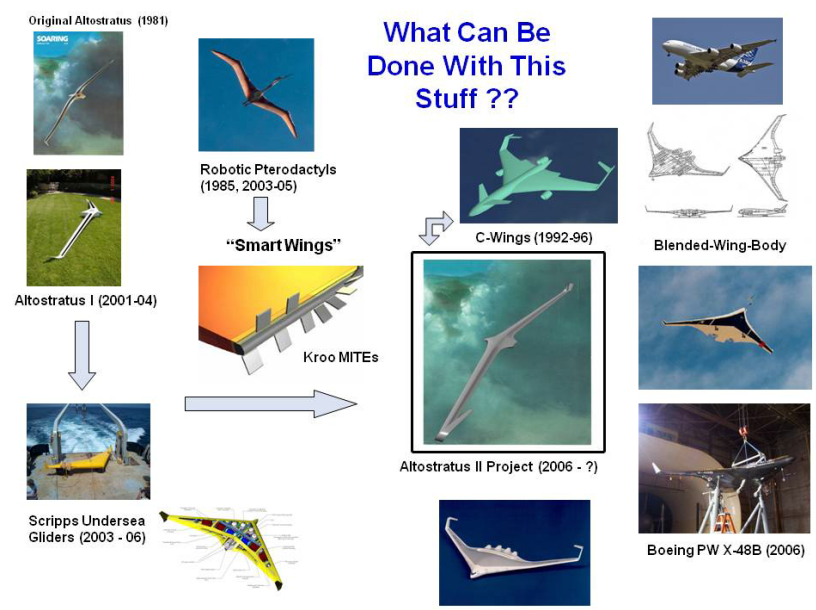

Figure 11. What Can Be Done With This Stuff?

Where would all of this lead? John was ready and waiting for us here as well. Expanding the base of aeronautical knowledge by including non-traditional sources of information would give students a larger base to operate from. Thinking outside of the box is certainly good, but expanding the box first and then thinking outside of it could be even better. John foresaw new challenges in aircraft design in the future, certainly with areas like "green airplanes" or "morphing airplanes" or mini/micro aerial vehicles with bio-inspired flight mechanisms. John could see that his "hobbies" would serve as good sources of information and inspiration for these new technical design challenges that require new methods and processes when compared with traditional commercial or military aircraft designs.

For example, the development of "green airplanes" will require increased energy efficiency from all disciplines, including aerodynamic efficiency, propulsion and fuels, weight and materials, and operations (such as air traffic management strategies, exploitation of atmospheric energy sources, etc.). Improvements in emissions $\left(\mathrm{CO}_{2}, \mathrm{NO}_{\mathrm{x}}\right.$, water vapor, etc.), noise, and disposability/recyclability will also be required. Many of these challenges will require new concepts and evolutionary thinking. Morphing aircraft concepts, such as those being suggested by NASA and DARPA, will require variable geometry airfoil and wing designs-we can certainly learn a great deal from birds about how to do this, as shown in Fig. 10. And mini/micro aerial vehicle design can learn from the study of insect flight, and the non-linear, unsteady aerodynamics that is inherent for these vehicles (also shown in Fig. 10).

One way to encourage and enable research in these areas is to create a new paradigm for "X-planes", as shown in Fig. 12. These new approaches use off the shelf model airplane technology to create experimental aircraft to test new ideas and concepts for relatively low cost, certainly below $\$ 100 \mathrm{~K}$ to $\$ 200 \mathrm{~K}$, and even as low as $\$ 1 \mathrm{~K}$ to $\$ 2 \mathrm{~K}$. Students at universities understood this long before the aircraft manufacturers did, as is evident by a new generation of students who do not wait to learn about aerodynamics or propulsion or structures, but instead build and test their concepts, much in the way that earlier innovators like the Wright Brothers did. While some experimentation will eventually require millions of dollars to complete concept validation, the initial low cost easily makes research at universities possible to sort out scores of concepts, leaving the final validation costs to the companies after candidate configuration or concepts have been proven. 


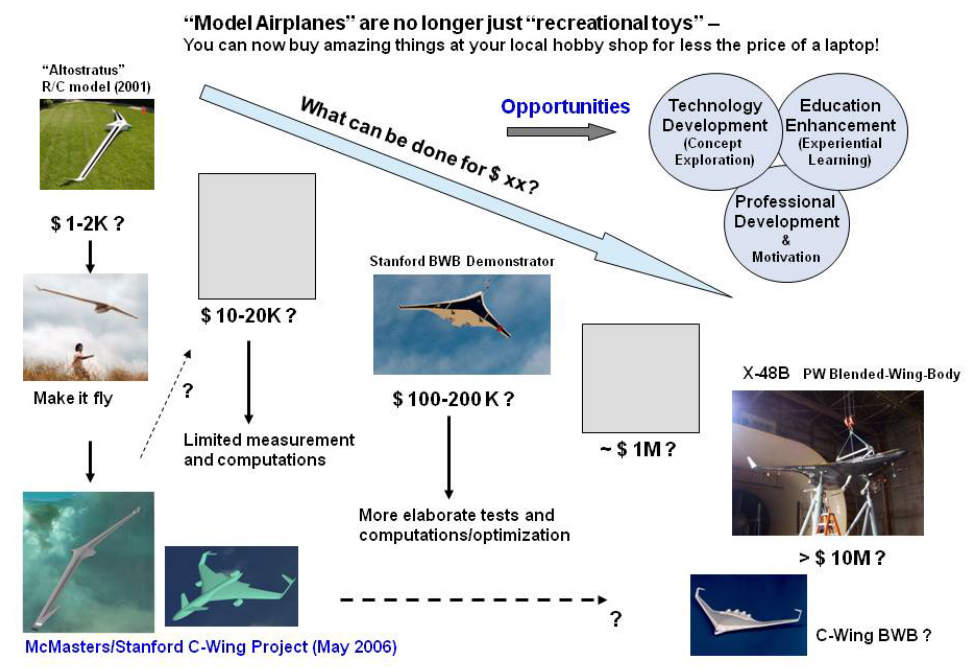

Figure 12. An "X-Planes" Continuum.

John even believed that this concept could be extended to various "Design-Build-Test" projects at universities, which could re-invigorate student creativity and create new technology, as shown in Fig. 13. John proposed that Boeing sponsor contests at universities (similar to the AIAA Design-Build-Fly competition) that would leverage student creativity with company resources to help solve future technology needs and goals of the company. The Boeing Technical Fellowship and Technology Interest Groups (TIGs, as described in Ref. 11) could be involved with the universities and help to mentor and advise the students as they progressed through the competition. This type of program would provide important "hands on" experience that would enhance the other educational and training opportunities described earlier. This would enhance the motivation, retention, and recognition of younger design talent.

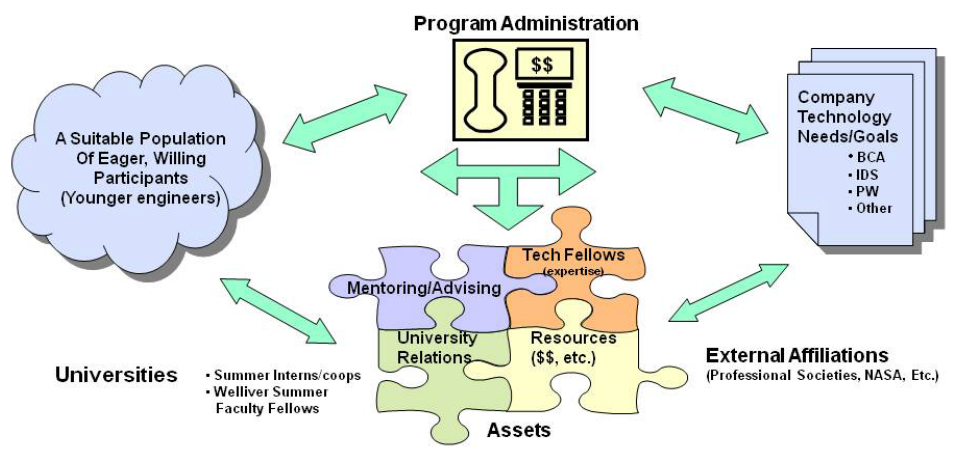

Figure 13. Micro/Mini “X-Planes” for Fun and Profit.

\section{Conclusions}

John McMasters was an accomplished aircraft designer and aerodynamicist who also had a passion for education. Late in his career he spent at least as much time devising educational concepts as he did devising design concepts, and his creativity and ingenuity are obvious in his ideas. His notions for improving engineering education could revolutionize how the engineering profession views education and continuing education, with the ability to satisfy the various interest groups who view education as important, including universities, governments, industry, and students. John's concepts for aircraft design education are very ingenious, and if implemented could supplement his overall approach to engineering education. His various hobbies, including studying dinosaur, insect, and bird flight, all could become essential to future aircraft design concepts that will enable the improved design of green airplanes, morphing aircraft, and mini-micro aerial vehicles. We are all a little better off for having been around John McMasters, and he will be greatly missed. 


\section{Acknowledgments}

Obviously, this paper would not have been possible without the generous mentorship of John McMasters. John was supportive of many people throughout his career, and I am honored that he gave so much support to me. In addition, I am grateful to The Boeing Company and their A.D. Welliver Faculty Summer Fellowship program. I feel honored to have been able to spend a summer with John and other engineers at Boeing. Finally, I should point out that all of the figures used in this paper were created by John McMasters!

\section{References}

${ }^{1}$ McMasters, J.H. and Cummings, R.M., "Airplane Design-Past, Present and Future," AIAA 39 $9^{\text {th }}$ Aerospace Sciences Meeting, Reno NV, AIAA Paper 2001-0535, Jan. 2001.

${ }^{2}$ McMasters, J.H. and Cummings, R.M., "The Demise of Aerospace-We Doubt It," Flight Journal, Aug. 2001, pp. 97-98.

${ }^{3}$ McMasters, J.H. and Cummings, R.M., "Airplane Design-Past, Present and Future," Journal of Aircraft, Vol. 39, No. 1, 2002, pp. 10-17.

${ }^{4}$ McMasters, J.H. and Cummings, R.M., "Airplane Design as a Social Activity-Emerging Trends in the Aerospace Industry," AIAA 40 ${ }^{\text {th }}$ Aerospace Sciences Meeting, Reno NV, AIAA Paper 2002-0516, Jan. 2002.

${ }^{5}$ McMasters, J.H. and Cummings, R.M., "From Farther, Faster, Higher to Leaner, Meaner, Greener-Further Directions in Airplane Design," AIAA 41 ${ }^{\text {st }}$ Aerospace Sciences Meeting, Reno NV, AIAA Paper 2003-0553, Jan. 2003.

${ }^{6}$ McMasters, J.H. and Cummings, R.M., "From Farther, Faster, Higher to Leaner, Meaner, Greener-Further Directions in Airplane Design," Journal of Aircraft, Vol. 41, No. 1, 2004, pp. 51-61.

${ }^{7}$ McMasters, J.H. and Cummings, R.M. "Airplane Design and the Biomechanics of Flight-A More Completely Multidisciplinary Perspective," AIAA 42 ${ }^{\text {nd }}$ Aerospace Sciences Meeting, Reno NV, AIAA Paper 2004-0532, Jan. 2004.

${ }^{8}$ McMasters, J.H. and Cummings, R.M., "Rethinking the Airplane Design Process-An Early 21st Century Perspective," AIAA 42 ${ }^{\text {nd }}$ Aerospace Sciences Meeting, Reno NV, AIAA Paper 2004-0693, Jan. 2004.

${ }^{9}$ McMasters, J.H. and Cummings, R.M., "Some Systemic Issues in the Development of the Aerospace Industry Technical Workforce of the Future," AIAA 42 ${ }^{\text {nd }}$ Aerospace Sciences Meeting, Reno NV, AIAA Paper 2004-1376, Jan. 2004.

${ }^{10}$ McMasters, J.H., and Cummings, R.M., "Those with Imagination but Not Learning Have Wings but No Feet—21st Century Challenges for Engineering and Education," The BENT of Tau Beta Pi, Summer 2004, pp. 12-19.

${ }^{11}$ Cummings, R.M. and McMasters, J.H., "Technology and You: Working with the Aerospace Industry to Enhance Engineering Education," ASEE Annual Conference, Portland OR, ASEE Paper 2005-0925, June 2005.

${ }^{12}$ McMasters, J.H., "Reflections on a Very Long Career in Aeronautics," Jan. 2006.

${ }^{13}$ McMasters, J.H., "Influencing Engineering Education-One [Aerospace] Industry Perspective," International Journal for Engineering Education, Vol. 20, No. 3, 2004, pp. 353-371.

${ }^{14}$ McMasters, J.H., "The Design Professor as Sheepherder (An Industry Role in Enhancing Engineering Education)," AIAA/AHS/ASEE Aircraft Design and Operations Meeting, Dayton OH, AIAA Paper 90-3259, Sept. 1990.

${ }^{15}$ McMasters, J.H. and Ford, S.D., “An Industry View of Enhancing Design Education,” Engineering Education, Vol. 80, No.5, 1990, pp. 526-529.

${ }^{16}$ McMasters, J.H., White, B.J., and Okiishi, T.O., "Industry-University-Government Roundtable for Enhancing Engineering Education (IUGREEE) - A History, Status and Future Plans," AIAA $37^{\text {th }}$ Aerospace Sciences Meeting, Reno NV, AIAA Paper 99-0281, Jan. 1999.

${ }^{17}$ McMasters, J.H., and Henderson, M.L., "Some Recent Applications of High-Lift Computational Methods at Boeing," AIAA Aircraft Systems and Technology Conference, Dayton OH, AIAA Paper 81-1657, Aug. 1981.

${ }^{18}$ McMasters, J.H., "Some Opportunities for Progress in Ultra-Light Aeronautics," Soaring, Vol. 39, No. 6, June 1975.

${ }^{19}$ McMasters, J.H., Kroo, I., Bofah, K.K., Sullivan, J.P., Drela, M., “Advanced Configurations for Very Large Subsonic Transport Airplanes," NASA CR 198351, Oct. 1996.

${ }^{20}$ McMasters, J.H., "Reflections of a Paleoaerodynamicist," Perspective in Biology and Medicine, Vol. 29, No. 3, Part 1, 1986, pp. 331-384.

${ }^{21}$ McMasters, J.H. "The Biomechanics of Flight-Many Possible Solutions Looking for Problems," International Journal for Engineering Education, Vol. 20, No. 3, June 2004, pp. 398-404.

${ }^{22}$ Cummings, R.M. and Hall, D., "Aircraft Design for Second-Year Undergraduate Students," International Journal of Engineering Education, Vol. 21, No. 2, 2005, pp. 341-349. 